lmages in...

\title{
Calcific visceral pericardial constriction
}

\author{
Ranjan K Shetty, ${ }^{1}$ G Vivek, ${ }^{1}$ Lorraine Simone Dias ${ }^{2}$ \\ 1Department of Cardiology, Kasturba Medical Hospital, Manipal, India; \\ ${ }^{2}$ Department of Internal Medicine, Kasturba Medical Hospital, Manipal, India
}

Correspondence to G Vivek, vivekgraman@gmail.com

\section{DESCRIPTION}

A middle-aged hypertensive lady was admitted with progressive weight gain and generalised edema of 1-year duration. Examination revealed a raised jugular venous pressure, anasarca, atrial fibrillation and no significant murmurs. Evaluation revealed mild anaemia with raised erythrocyte sedimentation rate. Chest radiograph and echocardiography revealed cardiomegaly, biatrial enlargement, IVC congestion, moderate pericardial effusion and significant atrioventricular valve respiratory variation. Fluoroscopy and catheterisation study showed pericardial calcification (figure 1, arrows) and confirmed findings of constrictive physiology with a typical 'square-root configuration'. CT scan (figure 2, arrows) showed pericardial effusion with thin, linear visceral pericardial calcification seen at the level of main pulmonary trunk and base of the heart in relation to the right and left ventricles sparing the parietal pericardium. The patient underwent surgical pericardiectomy. Thick whitish fibrous peel (figure 3, arrows) encircling the heart with calcification over the right ventricle and its outflow tract was dissected carefully. Four hundred millilitres of serosanguinous fluid was drained. Parietal pericardium was normal. Biopsy showed inflammatory infiltrates, fibrocollagenous tissue and no granulomas. Idiopathic isolated visceral calcific constriction was diagnosed, which is rare. ${ }^{1}$ Patient at 6

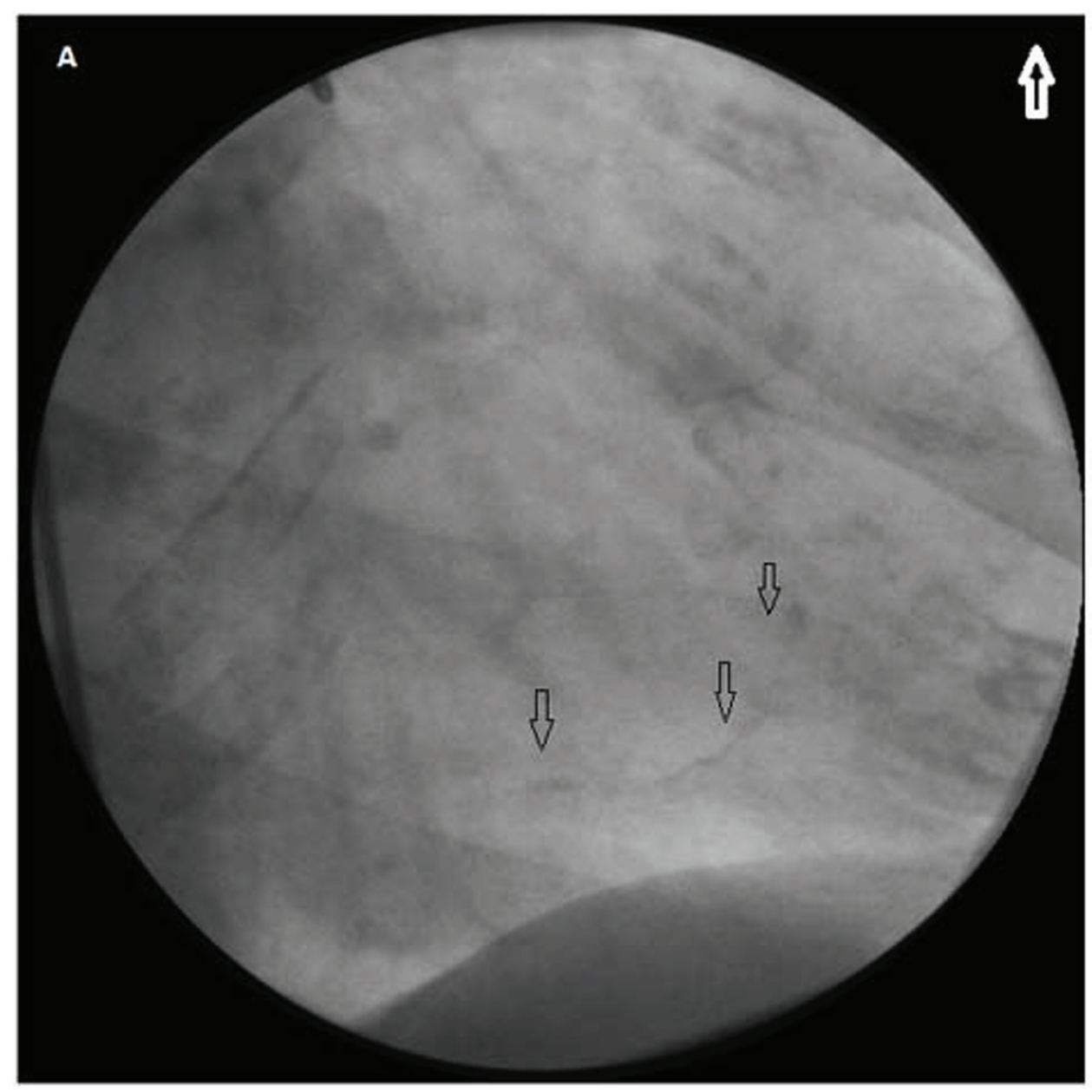

Figure 1 Fluoroscopy showing linear pericardial calcification (arrows). 


\section{BMJ Case Reports}

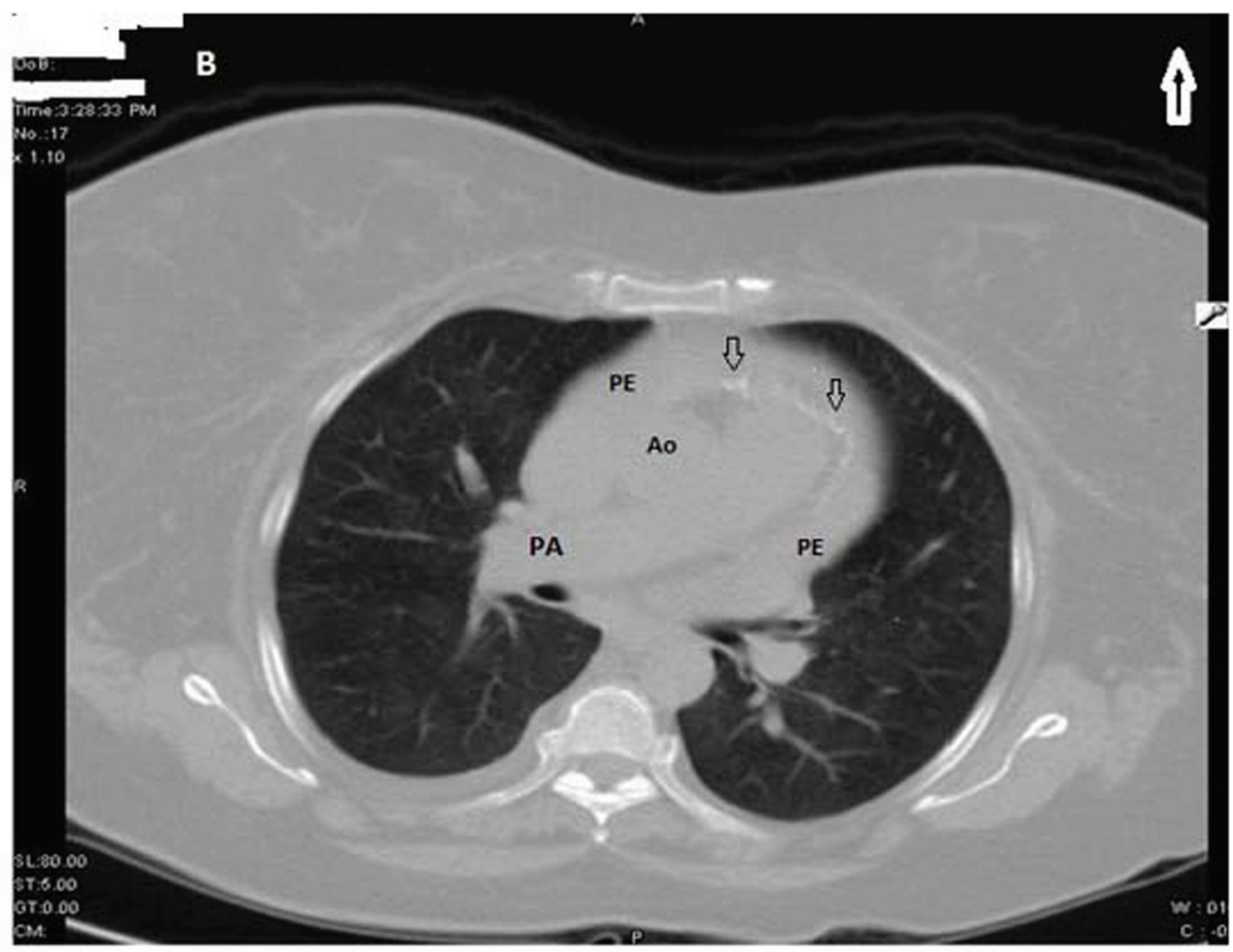

Figure 2 CT image of the chest showing pericardial effusion with thin, linear visceral pericardial calcification (arrows) seen at the level of main pulmonary trunk and base of the heart in relation to the right and left ventricles sparing the parietal pericardium. Ao, aorta; PA, pulmonary artery; and $\mathrm{PE}$, pericardial effusion.

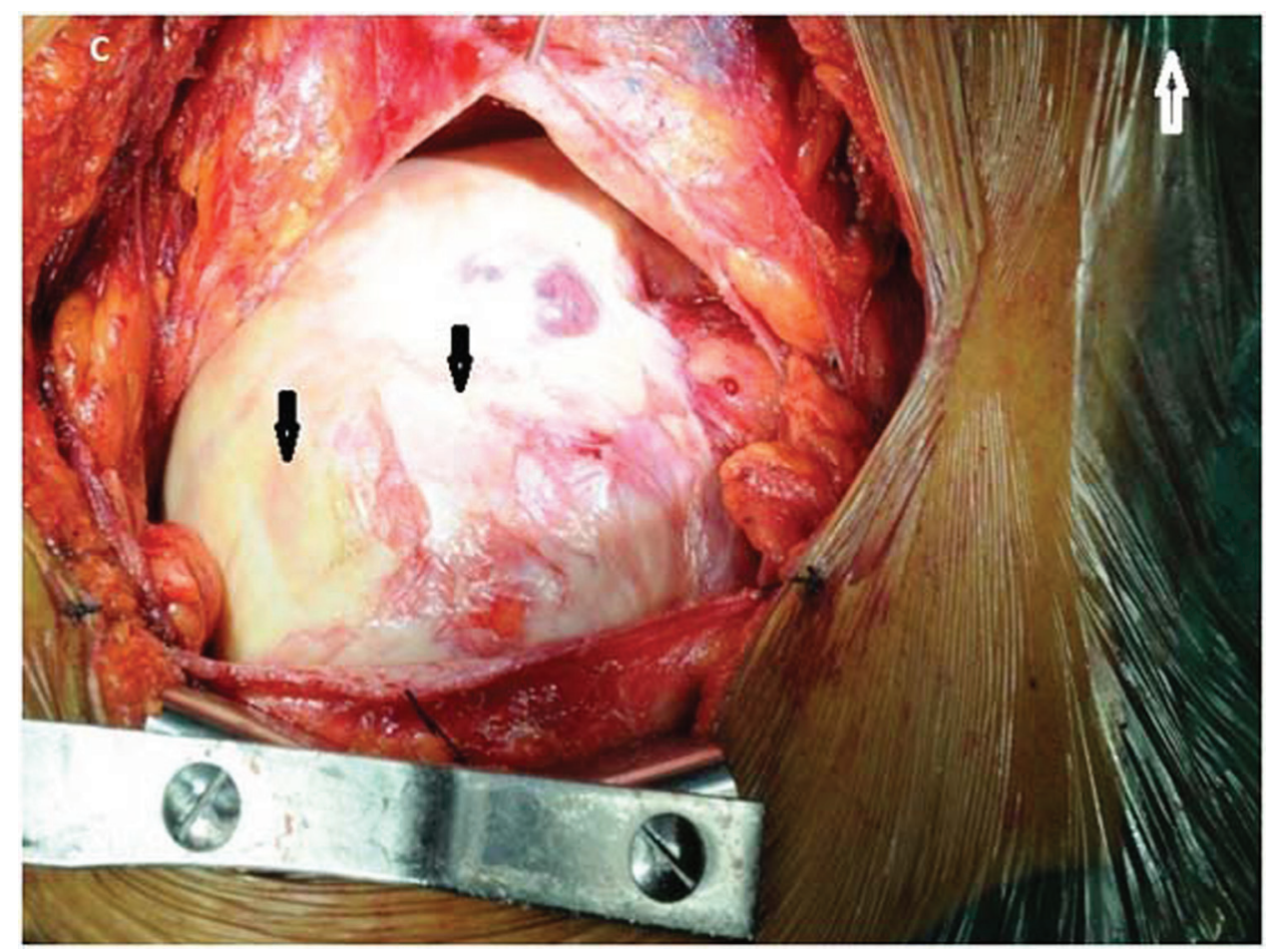

Figure 3 Intraoperative image showing thick whitish fibrous peel (arrows) encircling the heart. 


\section{BMJ Case Reports}

months follow-up had lost $15 \mathrm{~kg}$ and was in New York Heart Association class I.

Competing interests None.

Patient consent Obtained.

\section{REFERENCES}

1. Sagristà-Sauleda J, Angel J, Sánchez A, et al. Effusive-constrictive pericarditis. N Engl J Med 2004;350:469-75.

This pdf has been created automatically from the final edited text and images.

Copyright 2011 BMJ Publishing Group. All rights reserved. For permission to reuse any of this content visit http://group.bmj.com/group/rights-licensing/permissions.

BMJ Case Report Fellows may re-use this article for personal use and teaching without any further permission.

Please cite this article as follows (you will need to access the article online to obtain the date of publication).

Shetty RK, Vivek G, Dias LS. Calcific visceral pericardial constriction.

BMJ Case Reports 2011;10.1136/bcr.02.2011.3899, date of publication

Become a Fellow of BMJ Case Reports today and you can:

- Submit as many cases as you like

- Enjoy fast sympathetic peer review and rapid publication of accepted articles

Access all the published articles

- Re-use any of the published material for personal use and teaching without further permission

For information on Institutional Fellowships contact consortiasales@bmjgroup.com

Visit casereports.bmj.com for more articles like this and to become a Fellow 